\title{
A Study on Effectiveness of Online Learning System during COVID-19 in Sargodha
}

\author{
Ijaz Hussain \\ The University of Lahore, Sargodha Campus \\ Ijaz.hussain@ell.uol.edu.pk \\ Rana Muhammad Basharat Saeed \\ The University of Lahore, Sargodha Campus \\ engr.basharatrana@gmail.com \\ Ali Furqan Syed \\ The University of Lahore, Sargodha Campus \\ ali.syed@ell.uol.edu.pk
}

DOI: http://doi.org/ 10.36892/ijlls.v2i4.404

\begin{tabular}{ll}
\hline Received: & Abstract \\
30/09/2020 & The novel coronavirus (COVID-19) is known to be the worst pandemic on the \\
planet which has not only affected humankind very severely but also frozen all \\
Accepted: \\
areas of life on the sphere. The pandemic caused the largest turmoil in the \\
field of education across the world. The conventional system of education has \\
been disrupted resulting in the closure of all educational institutions around \\
the globe. The exams were postponed which made the students more \\
Keywords: \\
Concerned about their academic achievements. The educationists around the \\
learning, Traditional \\
learning, Effectiveness, \\
Learner.
\end{tabular}

\section{INTRODUCTION}

The current outbreak of novel coronavirus named COVID-19; a catastrophic pandemic originally emerged in Wuhan, China, in December, 2019, and spread all around the globe within no time. It is an acute respiratory epidemic that has a predisposition to be transmitted from one infected person to another as a life-threatening virus (Huang et al., 2020; Thorat, Mali, \& Pratap, 2020). The World Health Organization (WHO) officially identified this virus on $7^{\text {th }}$ January 2020 and named it 2019-nCoV (Thorat et al., 2020). On $30^{\text {th }}$ January 2020, the WHO declared public 
health emergency of international concern and also declared COVID-19 as a pandemic on $11^{\text {th }}$ March 2020 (Anwar \& Adnan, 2020). As a global response, the world saw a 'great lockdown' closing down all the business forums, organizational activities, and educational institutions. Any form of socialization was highly discouraged and ultimately restricted in all affected countries across the world to prevent the spread of COVID-19. The global recession due to COVID-19 resulted in the free fall of the world economy (Gros, 2020).

In the present scenario of COVID-19, the area of education, similar to other fields of life, has seriously been affected. The conventional way of learning at schools, colleges, and universities has been clogged altogether both in developed and underdeveloped countries. In order to cope with this dilemma, the countries started looking at some alternative to continue educating their students at home. The only way out was the online learning which was considered as the turning point in the educational system all around the world. Online learning has been partially practised in the developed and least practised in the underdeveloped countries, but the current pandemic situation has completely transformed the conventional system of education into a virtual system of education. Online learning is a form of distance learning which provides an online platform to teach the students utilizing modern online tools such as smartphone, tablet, computer, or laptop with the access of fast internet connection (Wan, 2020).

Pakistan like other Asian countries was also seriously affected by COVID-19. The government of Pakistan with limited resources took meticulous measures to control the spread of this deadly virus (Waris, Khan, Ali, Ali, \& Baset, 2020). On 26th February 2020, the Federal Health Ministry in Pakistan confirmed the first two cases of COVID-19 in Islamabad and Karachi. Subsequently, the government imposed partial and complete lockdown within the cities around the country restricting the potential activities of socialization, which remained successful and proved effective later on (Umer \& Khan, 2020).

As no one knows when this grave virus will leave our planet, the educational institutions around the world preferred to utilize the already existing technical resources on the way to promote online learning. In Pakistan, to execute social distancing procedures during COVID-19, the Higher Education Commission (HEC) gave directives to higher education institutions to initiate distance learning (DL). As a result, a regular online teaching-learning system was adopted to educate students while staying at home. As a matter of fact, the transformation from a conventional learning system to a new digital learning system is a little challenging and will take time to get accepted and established. Since this system is newly adopted in the underdeveloped countries; therefore, educational institutions will have to redesign their curriculum for online teaching-learning. In keeping with the instructions of the WHO, better learning outcomes can only be achieved through effective online delivery of content which is possible only by providing digital literacy training to teachers and students (Anwar \& Adnan, 2020).

In the modern world, English as an international language has been established as a fundamental vehicle of communication (Yassin, Abdul Razak, Qasem, \& Saeed, 2020). Urdu is the national language of Pakistan. It was declared as an official language of the country under 1973 constitution of Pakistan. Though Urdu is a national and official language, however, English has also been treated as an official language of communication in parallel with Urdu. For instance, the decisions made by the Supreme Court of Pakistan are produced both in Urdu and English. Due to its global recognition, English as a medium of education has become the most preferred language in Pakistan like other Asian and African countries (Shamim, 2017). The present research has focused online English language learning during COVID-19 in Sargodha, an 
educational district in Pakistan. The study highlighted the importance and overall effectiveness of the online learning system considering any future pandemic situation like COVID-19.

\section{LITERATURE REVIEW}

There are three major types of classrooms that exist in the educational system across the world. The first is the traditional classroom where textbooks, notebooks, pens, blackboards, etc., are used as teaching aids. The second one is the modern classroom in which the classroom is provided with whiteboards, audio-visual displays, digital boards, and overhead projectors. The third one is the latest which is the virtual classroom where online education is carried out using information and communication technologies (ICTs) to assist learning from different remote locations. It includes audio, video, and text communication using different software with access to the internet (Basilaia \& Kvavadze, 2020).

Online learning appeared as a major revolution in the modern educational system across the sphere during the $21^{\text {st }}$ century. Online learning or e-learning offers flexible modes of learning without physical presence of individuals in the traditional classroom. The virtual classroom environment provides an opportunity for students to become independent learners using innovative, efficient, informative, and effective tools of online learning. Effective content delivery, interactivity, collaboration, assessment, and evaluation are the pillars of a virtual classroom environment. Virtual classroom demands different modes of interaction such as peerpeer interaction, student-instructor interaction, and student-content interaction. Various technological aids need to function efficiently for effective implementation of online learning system, and students must know why, how, and when to employ online learning to get maximum benefits of the system (Subramaniam \& Kandasamy, 2011).

From a learning point of view, the technologies used in the virtual classroom are far more beneficial as compared to a conventional classroom. The interactive learning methodologies and web-based tools provide additional benefits to the students which are not the part of traditional classroom. It facilitates communication between teachers and students using multiple communication tools such as video conferencing provided with the online whiteboards, screen sharing, and real-time opportunity for video participation through which students can get the utmost input. Activity groups can also be created to promote coordination among peers (Haq, Shahzad, Ahmed, Hussain, \& Sajid, 2018). Online learning accompanies a number of advantages over conventional learning. The results revealed that online learning inculcates creative thinking in students. They become independent and future-oriented learners to solve their academic problems by obtaining relevant information from various sources on internet. It develops positive habits of learning as a part of mental development of students. The in-depth information and positive attitude towards learning indicate the practical value of virtual learning (Varzaneh \& Baharlooie, 2015). A research was conducted in Iran to compare online learning with lecturebased learning; the outcomes clearly indicated that online learning design was more effective if compared to lecture-based learning. However, further research is required to generalize these findings (Moazami, Bahrampour, Azar, Jahedi, \& Moattari, 2014).

Virtual classrooms (VCR) are provided with more interactive facilities such as presentation tools, screen sharing, online whiteboard, real-time videos etc. Employing these facilities help the instructor and the student to communicate using multiple faces. The VCR is advanced with the facilities of group communication as well as the method of submitting assignments, managing quizzes, and conducting exams. The whole information about learners 
and instructor is stored in the database to make VCR more effective. To get maximum output, activity groups are formed which provide an online discussion platform (Haq et al., 2018).

No doubt, the introduction of information technology and the internet in the field of education is an important development, but the virtual classroom cannot be the replacement of the traditional classroom. There is a complementarity between virtual classroom and traditional classroom (Razak, Yassin, \& Maasum, 2020). The findings uncovered that traditional classroom is the best option for anyone willing to be educated. As a matter of fact, both learning methods are discrete in nature and are equally important. When both are employed in combination, the better outcomes can surely be expected (Yan \& Song, 2013).

The word e-learning stands for electronic learning which means the process of learning using Information and Communication Technologies (ICTs) and now e-learning has become an essential part of the modern educational system. Being difficult and somehow problematic, the employment of ICTs into traditional ways of education is imperative to bring about quality and effectiveness in education. Educational technology is generally said to be the 'instructional technology' which accompanies systematic instructional design to fulfill the needs of the educational system. Employment of different models of instructional technology in the educational system will definitely help in upgrading the traditional system of education and create lifelong innovation in the teaching-learning process (Drozdova, 2007). In the present pandemic situation, CBTs (Cloud-based Tools) and MOOCs (Massive Open Online Courses) gained noteworthy acceptance among teachers and students in a number of educational institutions and are frequently practised for online learning. MOOCs facilitate learning with a broad range of topics to a massive number of students from diverse backgrounds. Various useful CBTs may be introduced in MOOCs with great acceptance from teachers and students (Shehadeh \& Guetl, 2016).

Online learning provides an increased access to updated information along with mutual interactions and collaboration. Some latest internet tools such as WebQuest and WebCT are now frequently employed in teaching to promote active learning among the learners. However, in online learning, a number of available links and related information might overwhelm and confuse the users which may be considered as a perceived disadvantage of the web-based technology. On the other hand, there is an element of increased reliance in traditional modes of teaching based on printed materials. Traditional learning is a socially acceptable pattern encompassing bulk amount of knowledge and information in the form of textbooks. Now Webbased courses are also being designed and introduced in virtual classrooms to improve learning outcomes (Mubaslat, 2012).

Many past studies have explored the effectiveness of online learning strategies. Employment of suitable strategies for online learning will surely be instrumental in pursuing the academic goals. In online learning, the learners learn more efficiently in a quick and pleasurable manner. Online language learning strategies (OLLS) play vital role in obtaining positive outcomes. Previous studies have also established relationship between academic achievements and online learning strategies. However, in some cases, learners did not show compatibility with the online learning environment and favoured traditional classroom settings, hence online learning strategies proved unfruitful. It has been revealed in some others studies that OLLS were less accomplished in Thailand (Kuama, 2016).

Students feel boredom in conventional ways of teaching who wish to be advantaged by technology introducing new methods of teaching. In the educational process, computer has played a deep-seated role and established its place in world of communication technology due to 
its appeal to both teachers and students as an efficient and effective tool of communication. Many educational institutes have introduced innovative methods of teaching using instructional media (Arulselvi, 2011). It has been found from the analysis that instructional media proved instrumental in learning English grammar. The students who used instructional technology gained high scores as compared to the students who used conventional means of learning. Therefore, it is recommended that English teachers must encourage learners to use computeraided instructional tools (Arulselvi, 2011).

A study conducted on language learning also unveiled that the learners preferred classroom environment considering it more advantageous and effective over online language learning environment. Learners agreed that language learning with face to face interactions in the presence of instructors in a traditional classroom is far more effective than learning alone in an online setting for learning (S. Jabeen \& A. Thomas, 2015). A similar study carried out on English language learners to examine their language proficiency in an online learning environment suggested that the students with low English proficiency were lacking the skills and experience for online and self-directed language learning. They tend not to learn online (Kuama, 2016). Another research indicates that the employment of the internet in combination with traditional instructional methods into educational institutions is found to be more effective than sheer online learning. unquestionably, significant and positive outcomes can be obtained through the integration of the internet into the curriculum of an existing conventional system of education or redesigning the curriculum (Mubaslat, 2012).

Today, English, being an international language, has influenced almost all areas of life such as computer software, internet, satellite broadcasting, advertising, maritime communication, air traffic, academics, scientific research etc. The information in electronic retrieval system is stored in English is more than 80\% (Mubaslat, 2012). Since early 1970s, communicative approach of language teaching is known to be the most effective theoretical model as it demands open-ended activities in a communicative situation adopting natural language learning strategies in order to understand the pragmatic meanings of linguistic forms. It is important to do certain necessary modifications in the traditional methods of learning by introducing instructional strategies and incorporating appropriate technologies in the field of second language learning. Most of the teachers and the students feel that there is a requirement of incorporation of ICTs, particularly computer, internet and multimedia in ESL/EFL (S. S. Jabeen \& A. J. Thomas, 2015). The present research focused English language learning through online media during COVID-19 to know the effectiveness of online learning system.

Despite the advantages of e-learning, there are a number of challenges that have never been faced by the students in their traditional learning environment. The difficulties encountered in an online learning system could negatively impact students' educational performance. These difficulties may include their cognitive issues, technical anxieties, learning style preferences, etc. However, the studies unveiled that the use of effective and efficient tools, and suitable online learning strategies would lead to better educational achievements (Kuama, 2016). An online learning system is a bit thorny to adopt in the countries where it is new or not practised, however, little effort in understanding this system can provide countless benefits as compared to the conventional system. The only need is to train both the teachers and the students at school, college, and university levels to get used to employing the latest technological tools to develop an effective online teaching-learning system (Wan, 2020).

A number of authors, on the basis of their observations and experiences, have their own opinion about the effectiveness of online learning system. It is an ongoing debate for the last 
many years that cannot be concluded overnight. The current study is an exertion to tread on the same track to highlight the importance and effectiveness of the online system during the present crisis due to COVID-19 all around the globe.

\section{Research Problems}

Teachers and students are new to e-learning system in Pakistan, they are not very well aware of the most effective and efficient methods of the online teaching-learning process.

\section{Research Gap}

There are a few academic pieces of research carried out on online learning systems in Pakistan; more researches are yet to be performed to study the importance of online learning system. This research highlights the effectiveness of online learning during the pandemic situation due to COVID-19 in Sargodha.

\section{Study Objective}

In the present situation of COVID-19, the purpose of this research was to highlight the importance and effectiveness of online learning as the latest form of distance education system. The study also put an accent on the effectiveness of the online learning system in comparison with the conventional learning system.

\section{Theoretical Underpinnings}

The relevant theories and researches that have been discussed in the literature review come together configuring the context of the current study. In the theory of social constructivism, the education theorist Vygotsky defines the learning process as a "zone of proximal development" where a teacher, a learner, and a problem to be resolved exist. The teacher creates a social environment to assist the learner to assemble and construct the required knowledge to solve that problem (Picciano, 2017).So, according to Vygotsky, the learning process is a problem-solving process. Applying the theory of social constructivism on the current pandemic situation of COVID-19 when the whole conventional learning system has been clogged across the world, online learning can be considered an effective solution to this problem to carry on the process of learning. A theoretical framework for effective learning during COVID-19 is given below.

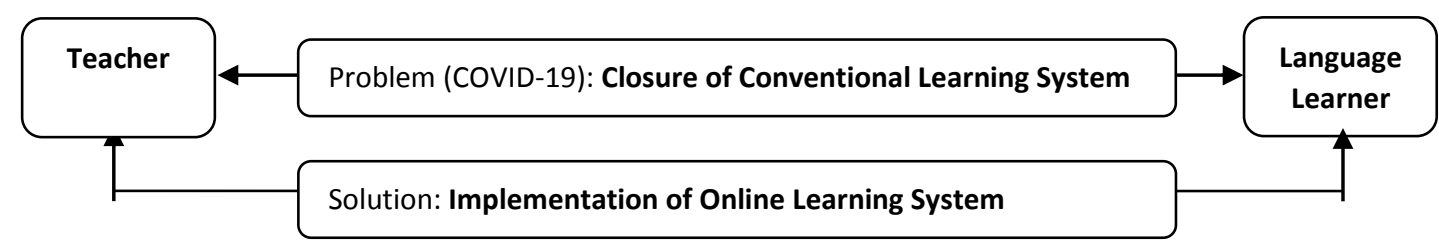

\section{METHODOLOGY}

(Huang, Liu, Tlili, Yang, \& Wang, 2020)

The present study is quantitative in nature, therefore, the descriptive and inferential statistical design was adopted to analyze the collected data (Ong \& Puteh, 2017).The population of the study included two educational institutions in Sargodha named Govt. High School (BlockY, New Satellite Town, Sargodha) and Army Public School \& College (Sargodha Cantt). Teachers of these two institutes were preferred as the research participants to get the factual 
results of this study. Convenient sampling technique was employed to sample the population, and the sample comprised fourteen participants from Govt. High School and twenty-two participants from Army Public School \& College. Since all the educational institutions are still closed in Pakistan due to the outbreak of COVID-19, therefore, an online questionnaire was developed on Google Drive with fifteen closely related closed-ended items to obtain the online responses of the participants (Delport, 2005; Roopa \& Menta Satya, 2012).

\section{RESULTS AND DISCUSSION}

The data were analyzed using SPSS (Statistical Package for Social Sciences), version 20. Descriptive statistics were applied to summarize and analyze the empirical data, and inferential statistics were used to determine the effectiveness of the online learning system (Greasley, 2007). In order to examine the effectiveness of the online learning system, the results have been presented in tabular form for further interpretation.

Online learning (or e-learning) is an alternate of conventional learning during the present pandemic wave of COVID-19.

\begin{tabular}{llllll}
\hline & Frequency & Percent & Valid Percent & $\begin{array}{l}\text { Cumulative } \\
\text { Percent }\end{array}$ \\
\hline \multirow{3}{*}{ Valid } & Strongly Agree & 23 & 63.9 & 63.9 & 63.9 \\
& Agree & 13 & 36.1 & 36.1 & 100.0 \\
& Total & 36 & 100.0 & 100.0 & \\
\hline
\end{tabular}

In the above Table, $23(63.9 \%)$ respondents 'strongly agreed' and $13(36.1 \%)$ respondents 'agreed' with the statement that online learning is an alternate of conventional learning during the present scenario of COVID-19. It indicates that teachers consider online learning as an alternate of conventional learning during pandemic situation due to COVID-19.

Online learning tools such as computer/ laptop, mobile, internet, social media, and different other social networks, are effective and efficient aids of the teachinglearning process at home.

\begin{tabular}{llllll}
\hline & Frequency & Percent & Valid Percent & $\begin{array}{l}\text { Cumulative } \\
\text { Percent }\end{array}$ \\
\hline \multirow{3}{*}{ Valid } & Strongly Agree & 22 & 61.1 & 61.1 & 61.1 \\
& Agree & 14 & 38.9 & 38.9 & 100.0 \\
& Total & 36 & 100.0 & 100.0 & \\
\hline
\end{tabular}

The above table illustrates that out of total 36 respondents, $22(61.1 \%)$ 'strongly agreed' and $14(38.9 \%)$ 'agreed' with the statement that online learning tools are effective and efficient aids of teaching-learning process at home. It shows that a big majority of the respondents was in favor of using online tools for distance learning. 
In the present era of technology, online learning tools are generally available to every learner at home.

\begin{tabular}{llllll}
\hline & Frequency & Percent & Valid Percent & $\begin{array}{l}\text { Cumulative } \\
\text { Percent }\end{array}$ \\
\hline \multirow{6}{*}{ Valid } & Strongly Agree & 1 & 2.8 & 2.8 & 2.8 \\
& Agree & 10 & 27.8 & 27.8 & 30.6 \\
& Neutral & 9 & 25.0 & 25.0 & 55.6 \\
& Disagree & 9 & 25.0 & 25.0 & 80.6 \\
& Strongly Disagree & 7 & 19.4 & 19.4 & 100.0 \\
Total & 36 & 100.0 & 100.0 & \\
\hline
\end{tabular}

The results mentioned in the above table showed that $1(2.8 \%)$ respondent 'strongly agreed' and $10(27.8 \%)$ respondents 'agreed' with the statement. Conversely, $9(25.0 \%)$ 'disagreed' and 7 (19.4) 'strongly disagreed' with the statement. It reveals that most of the respondents opposed the statement that online learning tools are available to every learner very where.

In online learning, a teacher can teach using more innovative teaching tools from anywhere at any time if compared to conventional learning.

\begin{tabular}{llllll}
\hline & & Frequency & Percent & Valid Percent & $\begin{array}{l}\text { Cumulative } \\
\text { Percent }\end{array}$ \\
\hline \multirow{4}{*}{ Valid } & Strongly Agree & 18 & 50.0 & 50.0 & 50.0 \\
& Agree & 17 & 47.2 & 47.2 & 97.2 \\
& Neutral & 1 & 2.8 & 2.8 & 100.0 \\
& Total & 36 & 100.0 & 100.0 & \\
\hline
\end{tabular}

The above table elucidates the importance and efficiency of the online learning system. Out of 36 respondents, 18 (50\%) respondents 'strongly agreed' and 17 (47.2\%) respondents 'agreed' that in online learning, a teacher can teach using more innovative teaching tools from anywhere at any time. It indicates that online learning is a prompt and effective method of learning if compared to conventional learning.

Online learning is more appealing as compared to conventional learning because it includes audios, videos, images, and tutorials etc.

\begin{tabular}{llllll}
\hline & & Frequency & Percent & Valid Percent & $\begin{array}{l}\text { Cumulative } \\
\text { Percent }\end{array}$ \\
\hline \multirow{4}{*}{ Valid } & Strongly Agree & 18 & 50.0 & 50.0 & 50.0 \\
& Agree & 17 & 47.2 & 47.2 & 97.2 \\
& Neutral & 1 & 2.8 & 2.8 & 100.0 \\
& Total & 36 & 100.0 & 100.0 & \\
\hline
\end{tabular}

The results in the above mentioned table explicate the advantages of online learning over traditional learning. There were $18(50 \%)$ respondents who 'strongly agreed' and $17(47.5 \%)$ respondents who 'agreed' with the statement. It illuminates that online learning is more appealing as compared to conventional learning because it includes audios, videos, images, and tutorials etc. 
Online learning gives the English language teachers and learners a worldwide exposure to enhance their knowledge on modern lines.

\begin{tabular}{llllll}
\hline & Frequency & Percent & Valid Percent & $\begin{array}{l}\text { Cumulative } \\
\text { Percent }\end{array}$ \\
\hline \multirow{4}{*}{ Valid } & Strongly Agree & 20 & 55.6 & 55.6 & 55.6 \\
& Agree & 15 & 41.7 & 41.7 & 97.2 \\
& Neutral & 1 & 2.8 & 2.8 & 100.0 \\
& Total & 36 & 100.0 & 100.0 & \\
\hline
\end{tabular}

The above table expounds that $20(55.6 \%)$ respondents 'strongly agreed' and $15(41.7 \%)$ respondents 'agreed' with the statement. It signifies that the maximum respondents accepted that online learning gives the English language teachers and learners a worldwide exposure to enhance their knowledge on modern lines.

Online learning requires less time for lesson delivery and lesson understanding because it is a quick and efficient way of learning if compared to conventional classroom settings.

\begin{tabular}{llllll}
\hline & Frequency & Percent & Valid Percent & $\begin{array}{l}\text { Cumulative } \\
\text { Percent }\end{array}$ \\
\hline \multirow{6}{*}{ Valid } & Strongly Agree & 15 & 41.7 & 41.7 & 41.7 \\
& Agree & 18 & 50.0 & 50.0 & 91.7 \\
& Neutral & 2 & 5.6 & 5.6 & 97.2 \\
& Disagree & 1 & 2.8 & 2.8 & 100.0 \\
& Total & 36 & 100.0 & 100.0 & \\
\hline
\end{tabular}

In the above table, (41.7\%) respondents 'strongly agreed' and $18(50 \%)$ respondents 'agreed' with the statement. Hence, an ample number of the respondents admitted that online learning is a quick and efficient way of learning if compared to conventional learning, and requires less time for lesson delivery and lesson understanding.

Voice messaging, video calls, screen sharing, and personal chats, are the more interactive features of online learning as compared to conventional learning.

\begin{tabular}{llllll}
\hline & & Frequency & Percent & Valid Percent & $\begin{array}{l}\text { Cumulative } \\
\text { Percent }\end{array}$ \\
\hline \multirow{6}{*}{ Valid } & Strongly Agree & 20 & 55.6 & 55.6 & 55.6 \\
& Agree & 15 & 41.7 & 41.7 & 97.2 \\
& Neutral & 1 & 2.8 & 2.8 & 100.0 \\
& Total & 36 & 100.0 & 100.0 & \\
\hline
\end{tabular}

The above table illustrates that there were 20 (55.6\%) respondents who 'strongly agreed' and $15(41.7 \%)$ respondents who 'agreed' with the statement that voice messaging, video calls, screen sharing, and personal chats, are the more interactive features of online learning as compared to conventional learning. It means that majority of the teachers think that online learning is more effective than conventional learning. 
Downloading of updated content at any time anywhere is an added feature of online learning which does not exist in conventional learning.

\begin{tabular}{llllll}
\hline & & Frequency & Percent & Valid Percent & $\begin{array}{l}\text { Cumulative } \\
\text { Percent }\end{array}$ \\
\hline \multirow{4}{*}{ Valid } & Strongly Agree & 16 & 44.4 & 44.4 & 44.4 \\
& Agree & 19 & 52.8 & 52.8 & 97.2 \\
& Neutral & 1 & 2.8 & 2.8 & 100.0 \\
& Total & 36 & 100.0 & 100.0 & \\
\hline
\end{tabular}

The above table highlights the results about the statement that downloading of updated content at any time anywhere is an added feature of online learning which does not exist in conventional learning. Out of the total respondents, $16(44.4 \%)$ respondents 'strongly agreed' and $19(52.8 \%)$ respondents 'agreed' that online learning provides opportunity to download academic stuff. It shows that most of the teachers truly appreciate the downloading feature of online learning which does not exist in conventional learning.

Online learning makes the English language learners the more independent learners knowing the right path of their learning while staying at home.

\begin{tabular}{llllll}
\hline & & Frequency & Percent & Valid Percent & $\begin{array}{l}\text { Cumulative } \\
\text { Percent }\end{array}$ \\
\hline \multirow{4}{*}{ Valid } & Strongly Agree & 17 & 47.2 & 47.2 & 47.2 \\
& Agree & 17 & 47.2 & 47.2 & 94.4 \\
& Neutral & 2 & 5.6 & 5.6 & 100.0 \\
& Total & 36 & 100.0 & 100.0 & \\
\hline
\end{tabular}

The above table contains the responses of the respondents about the statement that online learning makes the English language learners the more independent learners knowing the right path of their learning while staying at home. 17 (47.2\%) respondents 'strongly agreed' and an equal number of the respondents 'agreed' with the statement. It illuminates that teachers strongly favour online leaning which makes the learners the independent learners at home.

In online learning, the English language learners can improve their vocabulary and advance their overall language skills as compared to conventional learning which is limited to textbook.

\begin{tabular}{llllll}
\hline & Frequency & Percent & Valid Percent & $\begin{array}{l}\text { Cumulative } \\
\text { Percent }\end{array}$ \\
\hline \multirow{6}{*}{ Valid } & Strongly Agree & 17 & 47.2 & 47.2 & 47.2 \\
& Agree & 18 & 50.0 & 50.0 & 97.2 \\
& Neutral & 1 & 2.8 & 2.8 & 100.0 \\
& Total & 36 & 100.0 & 100.0 & \\
\hline
\end{tabular}

The data in the above table shows that 17 (47.2\%) respondents 'strongly agreed' and 18 $(50 \%)$ respondents 'agreed' with the statement that in online learning, the English language learners can improve their vocabulary and advance their overall language skills as compared to 
conventional learning which is limited to textbook. It indicates that teachers consider online learning instrumental in improving vocabulary and overall language skills of the learners.

Flexibility of timing as per comfort and availability of the teachers and the students is an excellent attribute of online learning if compared to conventional learning.

\begin{tabular}{llllll}
\hline & Frequency & Percent & Valid Percent & $\begin{array}{l}\text { Cumulative } \\
\text { Percent }\end{array}$ \\
\hline \multirow{6}{*}{ Valid } & Strongly Agree & 16 & 44.4 & 44.4 & 44.4 \\
& Agree & 18 & 50.0 & 50.0 & 94.4 \\
& Neutral & 1 & 2.8 & 2.8 & 97.2 \\
& Disagree & 1 & 2.8 & 2.8 & 100.0 \\
& Total & 36 & 100.0 & 100.0 & \\
\hline
\end{tabular}

In the above table, 16 (44.4\%) respondents 'strongly agreed' and 18 (50\%) 'agreed' with the statement that online learning provides flexibility of timing as per comfort and availability of the teachers and the students if compared to conventional learning. Hence, the results indicate that flexibility of timing as per comfort and availability of the teachers and the students is an excellent attribute of online learning.

Online learning is cost-effective as compared to the conventional method of learning because it reduces the cost of traveling, accommodation, and course materials.

\begin{tabular}{llllll}
\hline & Frequency & Percent & Valid Percent & $\begin{array}{l}\text { Cumulative } \\
\text { Percent }\end{array}$ \\
\hline \multirow{3}{*}{ Valid } & Strongly Agree & 17 & 47.2 & 47.2 & 47.2 \\
& Agree & 19 & 52.8 & 52.8 & 100.0 \\
& Total & 36 & 100.0 & 100.0 & \\
\hline
\end{tabular}

The results in table elucidate that out of a total of 36 respondents, 17 (47\%) respondents 'strongly agreed' and $19(52.8 \%)$ 'agreed' with the statement. It clearly indicates that all the respondents considered online learning as cost-effective compared to the conventional method of learning because it reduces the cost of traveling, accommodation, and course materials.

Online learning is a paperless way of learning, hence eco-friendly.

\begin{tabular}{llllll}
\hline & Frequency & Percent & Valid Percent & $\begin{array}{l}\text { Cumulative } \\
\text { Percent }\end{array}$ \\
\hline \multirow{6}{*}{ Valid } & Strongly Agree & 13 & 36.1 & 36.1 & 36.1 \\
& Agree & 17 & 47.2 & 47.2 & 83.3 \\
& Neutral & 2 & 5.6 & 5.6 & 88.9 \\
& Disagree & 4 & 11.1 & 11.1 & 100.0 \\
& Total & 36 & 100.0 & 100.0 & \\
\hline
\end{tabular}

The data in the above table includes the responses of the respondents about the statement that online learning is a paperless way of learning. There were $13(36.1 \%)$ respondents who 
'strongly agreed' and $17(47.2 \%)$ respondents who 'agreed' with the statement. Hence, the results highlight that online learning is eco-friendly.

Online learning is a preferred form of learning in higher education due to its easy availability, interactive nature, cost-effectiveness, access to updated content, and convenience of use.

\begin{tabular}{|c|c|c|c|c|c|}
\hline & & Frequency & Percent & Valid Percent & $\begin{array}{l}\text { Cumulative } \\
\text { Percent }\end{array}$ \\
\hline \multirow{3}{*}{ Valid } & Strongly Agree & 20 & 55.6 & 55.6 & 55.6 \\
\hline & Agree & 16 & 44.4 & 44.4 & 100.0 \\
\hline & Total & 36 & 100.0 & 100.0 & \\
\hline
\end{tabular}

The table illustrates that all the respondents acknowledged the online learning as a preferred form of learning in higher education due to its easy availability, interactive nature, cost-effectiveness, access to updated content, and convenience of use.

Further, a one-sample T-test was applied to determine the effectiveness of the online learning system on the basis of the data collected.

One-Sample Statistics

\begin{tabular}{lllll}
\hline & $\mathrm{N}$ & Mean & Std. Deviation & Std. Error Mean \\
\hline Effectiveness & 36 & 1.6667 & .41189 & .06865 \\
\hline
\end{tabular}

The above table illustrates that the mean $(1.66 \pm 0.41)$ for the effectiveness of the online learning system is lower than the pre-specified value for mean which was 3 .

One-Sample Test

\begin{tabular}{|c|c|c|c|c|c|c|}
\hline & \multicolumn{6}{|c|}{ Test Value $=3$} \\
\hline & \multirow[t]{2}{*}{$\mathrm{T}$} & \multirow[t]{2}{*}{ Df } & \multirow[t]{2}{*}{$\begin{array}{l}\text { Sig. } \\
\text { tailed) }\end{array}$} & \multirow[t]{2}{*}{$\begin{array}{l}\text { (2- } \text { Mean } \\
\text { Difference }\end{array}$} & \multicolumn{2}{|c|}{$\begin{array}{l}\text { 95\% Confidence Interval of } \\
\text { the Difference }\end{array}$} \\
\hline & & & & & Lower & Upper \\
\hline Effectiveness & -19.423 & 35 & .000 & -1.33333 & -1.4727 & -1.1940 \\
\hline
\end{tabular}

The sample means are significantly different as $\mathrm{p}(0.000)$ is less than Cronbach's alpha (.05) and the t-value is also very small as shown in the above table (Samuels \& Gilchrist, 2014). Hence, the results of the one-sample T-test clearly indicate that the online learning system is significantly effective during COVID-19 as per the objective of the research.

\section{Findings}

The following findings have been construed from the above data analysis:

- Most of the respondents considered online learning as an alternate of conventional learning during pandemic situation due to COVID-19.

- A big majority of the respondents was in favor of using online tools for distance learning.

- It has been revealed that most of the respondents opposed the statement that online learning tools are available to every learner very where.

- The results indicated that online learning was a prompt and effective method of learning if compared to conventional learning. 
- The results illuminated that online learning was more appealing as compared to conventional learning because it includes audios, videos, images, and tutorials etc.

- The results signified that the maximum respondents accepted that online learning gives the English language teachers and learners a worldwide exposure to enhance their knowledge on modern lines.

- An ample number of the respondents admitted that online learning was a quick and efficient way of learning if compared to conventional learning, and requires less time for lesson delivery and lesson understanding.

- Majority of the respondents agreed that online learning was more effective than conventional learning.

- Most of the respondents truly appreciated the downloading feature of online learning which does not exist in conventional learning.

- It has been uncovered that the respondents strongly favoured online leaning which makes the learners the independent learners at home.

- The results indicated that the respondents considered online learning instrumental in improving vocabulary and overall language skills of the learners.

- It has been inferred that flexibility of timing as per comfort and availability of the teachers and the students was an excellent attribute of online learning.

- The results highlighted that online learning is eco-friendly.

- The outcomes clearly indicated that all the respondents considered online learning as cost-effective compared to the conventional method of learning because it reduces the cost of traveling, accommodation, and course materials.

- All the respondents acknowledged the online learning as a preferred form of learning in higher education due to its easy availability, interactive nature, cost-effectiveness, access to updated content, and convenience of use.

- The results of the one-sample T-test unquestionably indicated that the online learning system was significantly effective during COVID-19.

Hence, the overall findings of the data analysis exposed that online learning system was the most effective learning system during the crisis caused by COVID-19. However, it has also been revealed that online learning tools may not be available to every learner everywhere.

\section{CONCLUSION}

Online learning is a distance learning system requiring no physical presence of the learner in the traditional classroom. In this system information and communication technologies (ICTs) are employed for effective delivery of the content at distant locations. The current study was conducted to highlight the effectiveness of the online learning system following social distancing measures during COVID-19. For this purpose, two educational institutes in Sargodha were chosen through convenient sampling to know the collective perception of the teachers involved in the study. Results were recorded using a questionnaire, and for quantitative data analysis, the descriptive and inferential statistical design was followed.

The overall results yielded that online learning was an effective and modern way of learning during COVID-19 to meet the educational needs of the students. It has been found that the adoption of online learning system would be advantageous during any pandemic like COVID-19 fulfilling the educational needs of the students staying at home. It has also been revealed that online learning is really helpful in advancing the overall language skills of English language learners. As a novel system of learning, there are a number of challenges being faced 
by the students in adopting online learning system. Although the participants considered the unavailability of the online learning tools as an obstacle on the way to distance learning particularly in remote areas, nonetheless, the overall inferences drew attention to the efficiency and effectiveness of the online learning system. Despite all the advantages, online learning can never be the replacement of traditional learning due to certain limitations of online learning system. However, it has finally been concluded that online learning system is the best substitute for conventional learning system during any pandemic situation like COVID-19.

\section{REFERENCES}

Anwar, K., \& Adnan, M. (2020). Online learning amid the COVID-19 pandemic: Students perspectives. Journal of Pedagogical Research, 1, 45-51. doi: 10.33902/JPSP.2020261309

Arulselvi, E. (2011). Effect of Instructional Media in the Learning of English Grammar on the Achievement of Teacher Training Students at Namakkal District. Journal on English Language Teaching, 1(3), 80-87.

Basilaia, G., \& Kvavadze, D. (2020). Transition to Online Education in Schools during a SARSCoV-2 Coronavirus (COVID-19) Pandemic in Georgia. Pedagogical Research, 5, 1-9. doi: $10.29333 / \mathrm{pr} / 7937$

Delport, C. (2005). Quantitative data collection methods. Research at grass roots for the social sciences and human service professions, 3, 159-191.

Drozdova, M. (2007). LEARNING TECHNOLOGY. Journal of Information, Control and Management Systems, 5.

Greasley, P. (2007). Quantitative data analysis using SPSS: an introduction for health \& social science: McGraw-Hill Education (UK).

Gros, D. (2020). The great lockdown: was it worth it? CEPS Policy Insights, May, online: https://www. ceps. eu/wp-content/uploads/2020/05/PI2020-11_DG_The-great-lockdown. $p d f$.

Haq, A., Shahzad, K., Ahmed, U., Hussain, S., \& Sajid, A. (2018). Web technologies used for virtual classroom.

Huang, R., Liu, D., Tlili, A., Yang, J., \& Wang, H. (2020). Handbook on facilitating flexible learning during educational disruption: The Chinese experience in maintaining undisrupted learning in COVID-19 Outbreak. Beijing: Smart Learning Institute of Beijing Normal University.

Huang, C., Wang, Y., Li, X., Ren, L., Zhao, J., Hu, Y., . . Cao, B. (2020). Clinical features of patients infected with 2019 novel coronavirus in Wuhan, China. The Lancet, 395. doi: 10.1016/S0140-6736(20)30183-5 
Jabeen, S., \& Thomas, A. (2015). Effectiveness of Online Language Learning.

Jabeen, S. S., \& Thomas, A. J. (2015). Effectiveness of online language learning. Paper presented at the World Congress on Engineering and Computer Science.

Kuama, S. (2016). Is Online Learning Suitable for All English Language Students? PASAA: Journal of Language Teaching and Learning in Thailand, 52, 53-82.

Moazami, F., Bahrampour, E., Azar, M., Jahedi, F., \& Moattari, M. (2014). Comparing two methods of education (virtual versus traditional) on learning of Iranian dental students: A post-test only design study. BMC medical education, 14, 45. doi: 10.1186/1472-6920-1445

Mubaslat, M. M. (2012). The Impact of English Interactive Online on the Students' Achievement in English Language in Jordan. Online Submission.

Ong, M. H. A., \& Puteh, F. (2017). Quantitative data analysis: Choosing between SPSS, PLS, and AMOS in social science research. International Interdisciplinary Journal of Scientific Research, 3(1), 14-25.

Picciano, A. G. (2017). Theories and frameworks for online education: Seeking an integrated model. Online Learning, 21(3), 166-190.

Razak, N. A., Yassin, A. A., \& Maasum, T. N. R. T. M. (2020). Formalizing Informal CALL in Learning English Language Skills. In Enhancements and Limitations to ICT-Based Informal Language Learning: Emerging Research and Opportunities (pp. 161-182). IGI Global.

Roopa, S., \& Menta Satya, R. (2012). Questionnaire Designing for a Survey. The Journal of Indian Orthodontic Society, 46, 37-41. doi: 10.5005/jp-journals-10021-1104

Samuels, P., \& Gilchrist, M. (2014). Independent Samples t-test.

Shamim, F. (2017). English as the language of development in Pakistan: Issues, challenges and possible solutions.

Shehadeh, A., \& Guetl, C. (2016). The Application of Cloud-Based Tools in MOOCs: Experiences and Findings.

Subramaniam, N., \& Kandasamy, M. (2011). The virtual classroom: A catalyst for institutional transformation. Australasian Journal of Educational Technology, 27, 1388-1412. doi: 10.14742/ajet.900

Thorat, B., Mali, S., \& Pratap, A. (2020). The Rise of New Coronavirus Infection (COVID-19): A Recent Update. doi: 10.14744/ejmo.2020.22222 
Umer, H., \& Khan, M. S. (2020). Evaluating the Effectiveness of Regional Lockdown Policies in the Containment of Covid-19: Evidence from Pakistan.

Varzaneh, S. S., \& Baharlooie, R. (2015). The Effect of Virtual vs. Traditional Classroom Instruction on Creative Thinking of Iranian High School EFL Learners. English Language Teaching, 8(5), 177-188.

Wan, Y. S. (2020). Education during COVID-19.

Waris, A., Khan, A., Ali, M., Ali, A., \& Baset, A. (2020). COVID-19 outbreak: current scenario of Pakistan. doi: 10.1016/j.nmni.2020.100681

Yan, S., \& Song, R. (2013). Virtual classroom and traditional classroom. Paper presented at the 2013 Conference on Education Technology and Management Science (ICETMS 2013).

Yassin, A. A., Abdul Razak, N., Qasem, Y. A., \& Saeed Mohammed, M. A. (2020). Intercultural Learning Challenges Affecting International Students' Sustainable Learning in Malaysian Higher Education Institutions. Sustainability, 12(18), 7490.

\section{$\underline{\text { AUTHORS' BIOS }}$}

Ijaz Hussain is a Lecturer at the department of English Language and Literature, the University of Lahore Sargodha Campus. His research interests include search engine optimization with in the area of Applied Linguistics, Critical Discourse Analysis, and digital education system.

Rana Muhammad Basharat Saeed is the M.Phil Scholar, University of Lahore, Sargodha Campus; His area of interest is digital system of education, Sociolinguistics and Applied Linguistics.

Ali Furqan Syed is a Lecturer at the department of English Language and Literature, the University of Lahore Sargodha Campus. His area of focus is English Applied Linguistics and English Literature, Critical Discourse Analysis. 